\title{
Disability, psychological distress and quality of life in relation to cancer diagnosis and cancer type: population-based Australian study of 22,505 cancer survivors and 244,000 people without cancer
}

Grace Joshy ${ }^{1 *}$ D, Joanne Thandrayen ${ }^{1}$, Bogda Koczwara², Phyllis Butow ${ }^{3}$, Rebekah Laidsaar-Powell ${ }^{3}$, Nicole Rankin ${ }^{3}$, Karen Canfell ${ }^{3,4,5}$, John Stubbs ${ }^{6}$, Paul Grogan ${ }^{4}$, Louise Bailey ${ }^{7,8}$, Amelia Yazidjoglou ${ }^{1}$ and Emily Banks ${ }^{1,9}$

\begin{abstract}
Background: Improved survival means that cancer is increasingly becoming a chronic disease. Understanding and improving functional outcomes are critical to optimising survivorship. We quantified physical and mental healthrelated outcomes in people with versus without cancer, according to cancer type.

Methods: Questionnaire data from an Australian population-based cohort study (45 and Up Study $(n=267,153)$ ) were linked to cancer registration data to ascertain cancer diagnoses up to enrolment. Modified Poisson regression estimated age- and sex-adjusted prevalence ratios (PRs) for adverse person-centred outcomes-severe physical functional limitations (disability), moderate/high psychological distress and fair/poor quality of life (QoL) —in participants with versus without cancer, for 13 cancer types.
\end{abstract}

Results: Compared to participants without cancer $(n=244,000)$, cancer survivors $(n=22,505)$ had greater disability (20.6\% versus $12.6 \%$, respectively, $\mathrm{PR}=1.28,95 \% \mathrm{Cl}=(1.25-1.32))$, psychological $(22.2 \%$ versus $23.5 \%, 1.05(1.02-1.08))$ and poor/fair QoL (15.2\% versus 10.2\%; 1.28 (1.24-1.32)). The outcomes varied by cancer type, being worse for multiple myeloma (PRs versus participants without cancer for disability 3.10, 2.56-3.77; distress 1.53, 1.20-1.96; poor/ fair QoL 2.40, 1.87-3.07), lung cancer (disability 2.81, 2.50-3.15; distress 1.67, 1.46-1.92; poor/fair QoL 2.53, 2.21-2.91) and non-Hodgkin's lymphoma (disability 1.56, 1.37-1.78; distress 1.20, 1.05-1.36; poor/fair QoL 1.66, 1.44-1.92) and closer to those in people without cancer for breast cancer (disability 1.23, 1.16-1.32; distress 0.95, 0.90-1.01; poor/ fair QoL 1.15, 1.05-1.25), prostate cancer (disability 1.11, 1.04-1.19; distress 1.09, 1.02-1.15; poor/fair QoL 1.15, 1.081.23) and melanoma (disability 1.02, 0.94-1.10; distress 0.96, 0.89-1.03; poor/fair QoL 0.92, 0.83-1.01). Outcomes were worse with recent diagnosis and treatment and advanced stage. Physical disability in cancer survivors was greater in all population subgroups examined and was a major contributor to adverse distress and QoL outcomes.

\footnotetext{
* Correspondence: Grace.Joshy@anu.edu.au

'National Centre for Epidemiology and Population Health, Research School

of Population Health, Australian National University, Mills Road, Acton,

Canberra, ACT 2601, Australia

Full list of author information is available at the end of the article
}

(c) The Author(s). 2020 Open Access This article is licensed under a Creative Commons Attribution 4.0 International License, which permits use, sharing, adaptation, distribution and reproduction in any medium or format, as long as you give appropriate credit to the original author(s) and the source, provide a link to the Creative Commons licence, and indicate if changes were made. The images or other third party material in this article are included in the article's Creative Commons licence, unless indicated otherwise in a credit line to the material. If material is not included in the article's Creative Commons licence and your intended use is not permitted by statutory regulation or exceeds the permitted use, you will need to obtain permission directly from the copyright holder. To view a copy of this licence, visit http://creativecommons.org/licenses/by/4.0/ The Creative Commons Public Domain Dedication waiver (http://creativecommons.org/publicdomain/zero/1.0/) applies to the data made available in this article, unless otherwise stated in a credit line to the data. 
(Continued from previous page)

Conclusions: Physical disability, distress and reduced QoL are common after cancer and vary according to cancer type suggesting priority areas for research, and care and support.

Keywords: Survivorship, Cancer survivor, Disability, Psychological distress, Quality of life, Australian, Cohort

\section{Background}

With improved prevention, early detection and treatment, cancer survival has increased, and cancer is increasingly becoming a chronic disease. Hence, survivors are living with cancer and/or the adverse consequences of its treatment for extended periods of time, underscoring the importance of longer-term health care outcomes of survivors including attributes central to the ability of individuals and communities to lead rich and fulfilling lives $[1,2]$.

These "person-centred" outcomes-including mental health, disability, social and economic participation, and quality of life-have been identified as important by cancer survivors [3, 4]. However, despite the need for evidence on these outcomes, surprisingly, little is known about them $[5,6]$. Cancer is a highly heterogeneous condition, and recognition of the diversity of survivorship experiences is important. Many survivorship studies to date have involved small samples, single cancer types and short- to medium-term outcomes and/or lacked comparable individuals without cancer. Key previous large-scale studies have been restricted to older cancer survivors aged $\geq 65$ years $[7,8]$ or used self-reported cancer only [9-12]. None has permitted large-scale integrated consideration of the full range of more common cancer types and multiple key person-centred outcomes, relative to otherwise comparable individuals without cancer. There is also a lack of reliable evidence on the joint contributions of the diagnosis of cancer and physical disability to psychological distress and quality of life, although studies have shown relationships between these factors individually [13].

This study aimed to quantify short- and long-term physical and mental health-related person-centred outcomes in people with cancer, compared to people without cancer, for a range of cancer types-overall and according to time since diagnosis, stage and recent treatment for cancer, accounting for age and sex, in a population-based Australian study of over 260,000 participants. We hypothesised that physical disability would be a major contributing factor to high psychological distress and reduced quality of life in both cancer survivors and those without cancer [13].

\section{Methods}

The Sax Institute's 45 and Up Study is a populationbased cohort study of 267,153 men and women aged 45 and over, randomly sampled from the general population of New South Wales (NSW), Australia, using the Department of Human Services enrolment database. Participants aged 45 or over were enrolled to enable research into major diseases and health problems experienced in later life and provide reliable evidence to inform policy to support healthy ageing. The cohort includes approximately $10 \%$ of NSW residents in the eligible age group. Individuals joined the study by completing a self-administered postal questionnaire (distributed from 1 January 2006 to 31 December 2008) and giving informed consent for longterm follow-up and linkage of their data to other population health databases. The general study methods are described in detail elsewhere [14]. This study is part of an NHMRC-funded project; consumers have been involved with this project since its conception, with roles agreed between the researchers and consumers at each phase of the project (Additional file 1).

Baseline questionnaire data included self-reported information on demographic factors, medical and surgical history, height, weight, smoking, alcohol intake, physical activity, functional capacity, mental health and self-rated health and quality of life (measures described below). The study questionnaire is available at https://www.saxinstitute.org.au/our-work/45-up-study/questionnaires/.

Questionnaire data from study participants were linked probabilistically to administrative datasets including data from the NSW Central Cancer Registry (CCR, 1 January 1994 to 31 December 2013). This probabilistic matching was conducted by the NSW Centre for Health Record Linkage (CHeReL) and is known to be highly accurate (false-positive and false-negative rates $<0.4 \%$ ) [15]. The linked CCR data comprised records of all diagnosed cancers (except those C44 codes that indicate a basal cell carcinoma or a squamous cell carcinoma which are not notifiable diseases thus not reported to cancer registries) for NSW residents, including the date of diagnosis and International Classification of Diseases (ICD)-coded cancer types and sites. Following the exclusion of participants with invalid data on age or date of recruitment $(n=461$, $0.17 \%)$ or data linkage errors $(n=187,0.07 \%)$, the analysis dataset consisted of 266,505 individuals.

\section{Exposure}

The main exposure was a cancer diagnosis prior to the completion of the baseline questionnaire. Participants were classified as being a cancer survivor if they had a cancer diagnosis record in the CCR database in the 12 
years prior to baseline; the type, date of diagnosis and stage of cancer were also ascertained from the CCR database. A 12-year window, based on the availability of linked data, was used to ensure a uniform probability of identification of cancer previous diagnoses from CCR database for all participants. The 12 cancer types with the highest age-standardised incidence in Australia [16] were investigated separately a priori, except cancer of the pancreas which was excluded due to the small number of cases in the 45 and Up Study; oesophagal cancer and multiple myeloma were also included due to their known adverse impact on well-being. Cancer types were classified as breast (ICD-10 AM diagnosis code C50, women only), prostate (C61, men only), lung (C33C34), melanoma (C43), colorectal (C18-C20), nonHodgkin's lymphoma (NHL, C82-C86), kidney (C64), oesophagus (C15), uterus (C54-C55, women only), bladder (C67);,thyroid (C73), leukaemia (C91-C95) and multiple myeloma (C90.0) (Additional file 2: Table S1). All the remaining cancers were included in an "other cancers" category.

The time since diagnosis was classified as less than 1 year, 1 to $<5$ years, 5 to $<10$ years and 10 or more years. If multiple cancers were present, the diagnosis closest to the study enrolment date was used. The stage of cancer at diagnosis was classified as localised to the tissue of origin, regional spread to adjacent organs and/or regional lymph nodes, distant metastases and unknown stage (only solid cancers (ICD-10 AM diagnosis codes C00.0-C43.9 or C45.0-C80) were staged). Recent treatment was classified as yes/no based on the response to the baseline survey question, "In the last month, have you been treated for cancer?" The reference group for the study comprised respondents with no record of a cancer diagnosis in the CCR database.

\section{Outcomes}

Physical functioning limitations were assessed using the Medical Outcomes Study Physical Functioning (MOSPF) score [17] eliciting self-reported data on limitations in the ability to perform vigorous and moderate physical activities and tasks such as lifting or carrying shopping; climbing stairs; walking; bending, kneeling or stooping; and bathing or dressing. The MOS-PF is a valid and reliable measure of physical functioning [18], with a lower score indicating more severe functional limitation [19]. Scores ranged from 0 to 100 , where higher scores represented fewer limitations, and were grouped into four categories: no limitation (MOS-PF score $=100$ ), minor limitations (90-99), moderate limitations (60-89) and severe limitations $(<60)[14,19]$.

Psychological distress was assessed using the Kessler10 (K10), a validated measure of non-specific symptoms of psychological distress [20]. Respondents indicated the frequency of symptoms experienced in the past 4 weeks, from 1 "none of the time" to 5 "all of the time". Scores range from 10 (no distress) to 50 (severe distress) and were categorised as low distress (10 to < 16), moderate distress $(16$ to $<22)$ and high distress (22 to 50) [21].

Self-rated health and quality of life were based on the question, "In general, how would you rate your overall health/quality of life?", followed by response options of excellent, very good, good, fair and poor.

\section{Other variables}

Sociodemographic and health characteristics included age (categorised as $45-64$ years; $65-79$ years; $\geq 80$ years), gender, education (no school certificate, certificate/diploma/trade, university degree), country of birth (Australian born, not Australian born), body mass index (BMI $\left(\mathrm{kg} / \mathrm{m}^{2}\right) 15$ to $<18.5,18.5$ to $<25,25$ to $<30$, and $\geq 30$ 50), physical activity (tertiles of sessions per week weighted for intensity), smoking status (never/past/ current smoker) and number of alcoholic drinks per week ( $0,1-14, \geq 15$ drinks per week). The region of residence derived from the address was categorised as major city, inner regional, outer regional and remote/very remote. Comorbidities were based on responses to questions on "has a doctor ever told you that you have...".

\section{Statistical methods}

After logical imputation and backfilling for $\mathrm{K} 10$ and MOS-PF scores, we excluded those with missing data on each outcome variable (physical functioning limitations ( $n=35,450 ; 13.3 \%)$, psychological distress $(n=30,290$; $11.4 \%)$, self-rated health $(n=9413 ; 3.5 \%)$ and quality of life $(n=14,064 ; 5.3 \%))$ from the corresponding analyses.

Descriptive statistics summarised demographic and clinical data. Modified Poisson regression models estimated prevalence ratios (PRs) and 95\% confidence intervals (CIs) to quantify associations between a cancer diagnosis and each adverse person-centred outcome, categorised as binary variables: severe physical functioning limitations (MOS-PF score <60), high/moderate psychological distress (K10 score 16-50), poor/fair self-rated health, poor/fair quality of life, overall and according to cancer type. Models were adjusted for age and sex (where applicable). Further statistical adjustments were not done as the objective was to compare prevalences and lived experiences rather than establish causality. Adjusted PRs were also estimated stratifying by clinical characteristics (time since diagnosis, stage and recent treatment). To quantify the contribution of physical disability to high psychological distress, poor/fair quality of life and poor/fair self-rated health, adjusted PRs were estimated among participants with and without a cancer diagnosis further stratified by different levels of physical functional limitations; those with neither cancer nor physical functional 
limitations were used as the reference group. The prevalence of severe physical functioning limitations across population subgroups was compared, separately for those with and without cancer; differences by cancer diagnosis were assessed using interaction tests.

Sensitivity analyses examined further adjustment for educational attainment, as a proxy for socioeconomic status, as well as alternative binary classification of physical functioning limitations (MOS-PF score $<90$ indicating moderate/severe physical functioning limitations) and high psychological distress (K10 score 22-50 indicating high distress).

\section{Results}

There were 22,505 cancer survivors and 244,000 people without cancer included in the analysis. Compared to participants without cancer, cancer survivors were older and more likely to be male and former smokers and were similar with respect to other characteristics examined, including levels of education, urban/rural residence, body mass index, level of physical activity and alcohol intake (Table 1).

Of the 22,505 cancers identified, the most common were prostate $(26 \%)$, breast (19\%), melanoma (15\%) and colorectal (13\%) cancer, which accounted for nearly three quarters of all cancers (Table 2). Clinical characteristics such as time since diagnosis of cancer, cancer stage and recent treatment varied according to cancer type. The median time since diagnosis of cancer was 3.9 years, with $60 \%$ diagnosed in the 5 years prior to baseline (Table 2). Lung and oesophageal cancer survivors were more likely to have been diagnosed within the previous year compared to those with other cancers. For cancer types other than colorectal cancer, most had localised disease. The majority of survivors had not received cancer treatment in the past month, except for those with multiple myeloma (Table 2).

Overall, $21 \%$ of cancer survivors had severe physical functioning limitations, compared to $13 \%$ of people without cancer (age- and sex-adjusted PR 1.28, 95\%CI 1.25-1.32) (Table 1, Fig. 1). Similarly, elevated prevalences of fair/poor self-rated health and quality of life were apparent, with PRs for cancer survivors versus those without cancer of $1.41(1.37-1.45)$ and 1.28 (1.241.32), respectively (Fig. 1). The age- and sex-adjusted PR for moderate/high psychological distress was slightly elevated in cancer survivors $(1.05,1.02-1.08)$, although the crude prevalence was slightly lower $(22.2 \%$ in cancer survivors versus $23.5 \%$ in people without cancer). In general, adverse person-centred outcomes were elevated for all cancer types, with the exception of some cancers in relation to psychological distress (Fig. 1), and for melanoma across all outcomes. Outcomes varied substantively by cancer type. Almost half of those with multiple myeloma and lung cancer had severe physical functioning limitations; adjusted prevalences were around threefold those of cancer-free participants (Fig. 1). They also experienced the highest levels of distress and reductions in self-rated health and quality of life. In general, participants with non-Hodgkin's lymphoma (NHL), leukaemia and cancers of the oesophagus, uterus, bladder, thyroid and kidney had a prevalence of adverse person-centred outcomes that were below those observed in those with multiple myeloma and lung cancer and were higher than those observed for breast, colorectal and prostate cancers (Fig. 1). The composite group of less common "other cancers" (Additional file 2: Table S1) experienced consistent elevations in adverse person-centred outcomes, compared to people without cancer; PRs were at least 22\% higher for all outcomes (Fig. 1).

Although physical functioning, self-rated health and quality of life were reduced overall for cancer survivors compared to their cancer-free peers, worse outcomes were observed with increasing recency of diagnosis, more advanced stage and treatment within the last month. Compared to cancer-free participants, the PRs for severe physical functioning limitations were 1.47 (1.38-1.58) for cancer survivors diagnosed within the previous year and $1.19(1.14-1.25)$ after 5 or more years (Fig. 2). Corresponding PRs were 2.23 (1.98-2.50) for metastatic disease, $1.12(1.08-1.17)$ for localised disease, 1.89 (1.80-1.99) for cancer treatment in the previous month and 1.13 (1.091.17) for cancer survivors not receiving treatment in the previous month (Figs. 3 and 4). Similar patterns were observed for psychological distress, self-rated health and quality of life (Additional file 2: Fig. S1-S9). However, the magnitude of the differences in psychological distress between cancer survivors and cancer-free individuals was less pronounced, and long-term survivors showed no significant elevation in psychological distress 5 or more years post-diagnosis (1.01, 0.97-1.05; Additional file 2: Fig. S1).

Within each clinical characteristic group (e.g. time since diagnosis $<1$ year), there were large variations in person-centred outcomes according to cancer type, similar to those observed above; multiple myeloma and lung cancer patients experienced the worst outcomes, and patients with breast, colorectal and prostate cancer and melanoma patients had the best outcomes.

Among individuals with and without cancer, the prevalence of moderate/high psychological distress and fair/poor self-rated health and quality of life increased markedly with increasing limitations to physical functioning (Fig. 5).

Among participants without limitations to physical functioning, compared to cancer-free individuals, participants with cancer had a significantly reduced prevalence of moderate to high psychological distress $(0.88,0.81-0.96)$, a significantly elevated prevalence of fair/poor self-rated health 
Table 1 Characteristics of the study population

\begin{tabular}{|c|c|c|c|}
\hline & Cancer survivors $(n=22,505)$ & Participants without cancer $(n=244,000)$ & Total $(n=266,505)$ \\
\hline \multicolumn{4}{|l|}{ Age group } \\
\hline 45-64 years & $37 \%(8333)$ & $64 \%(155,223)$ & 163,556 \\
\hline $65-79$ years & $44 \%(9860)$ & $27 \%(65,989)$ & 75,849 \\
\hline$\geq 80$ years & $19 \%(4312)$ & $9 \%(22,788)$ & 27,100 \\
\hline Male & $56 \%(12,666)$ & $45 \%(110,951)$ & 123,617 \\
\hline University degree & $19 \%(4302)$ & $23 \%(57,161)$ & 61,463 \\
\hline Residing in major cities & $53 \%(11,970)$ & $52 \%(127,085)$ & 139,055 \\
\hline Australian born & $78 \%(17,443)$ & $75 \%(182,214)$ & 199,657 \\
\hline \multicolumn{4}{|l|}{ Body mass index, $\mathrm{kg} / \mathrm{m}^{2}$} \\
\hline Overweight $(25$ to < 30$)$ & $38 \%(8482)$ & $36 \%(88,825)$ & 97,307 \\
\hline Obese (30 to 50 ) & $21 \%(4759)$ & $22 \%(52,694)$ & 57,453 \\
\hline Highest physical activity tertile & $30 \%(6691)$ & $34 \%(82,273)$ & 88,964 \\
\hline Current smoker & $5 \%(1048)$ & $7 \%(18,244)$ & 19,292 \\
\hline Past smoker & $41 \%(9308)$ & $36 \%(86,885)$ & 96,193 \\
\hline$\geq 15$ alcoholic drinks per week & $14 \%(3228)$ & $14 \%(34,197)$ & 37,425 \\
\hline Cardiovascular disease & $25 \%(5567)$ & $17 \%(40,372)$ & 45,939 \\
\hline Diabetes & $11 \%(2583)$ & $9 \%(21,307)$ & 23,890 \\
\hline Parkinson's disease & $1 \%(243)$ & $1 \%(1430)$ & 1673 \\
\hline Asthma & 9\% (2111) & $10 \%(25,030)$ & 27,141 \\
\hline \multicolumn{4}{|c|}{ Physical functioning limitations (MOS-PF score) } \\
\hline Median score & 85 & 95 & 95 \\
\hline No limitation (100) & $21 \%(4078)$ & $35 \%(74,661)$ & 78,739 \\
\hline Minor limitations (90-99) & $27 \%(5151)$ & $29 \%(61,215)$ & 66,366 \\
\hline Moderate limitations (60-89) & $31 \%(5885)$ & $23 \%(49,437)$ & 55,322 \\
\hline Severe limitations $(<60)$ & $21 \%(3911)$ & $13 \%(26,717)$ & 30,628 \\
\hline \multicolumn{4}{|l|}{ Psychological distress (K10 score) } \\
\hline Median score & 12 & 12 & 12 \\
\hline Low distress (10-15) & $78 \%(14,720)$ & $76 \%(166,152)$ & 180,872 \\
\hline Moderate distress (16-21) & $16 \%(2968)$ & $16 \%(34,395)$ & 37,363 \\
\hline High distress (22-50) & $7 \%(1245)$ & $8 \%(16,735)$ & 17,980 \\
\hline \multicolumn{4}{|l|}{ Self-rated health } \\
\hline Excellent & $8 \%(1808)$ & $16 \%(37,057)$ & 38,865 \\
\hline Very good & $31 \%(6683)$ & $37 \%(88,204)$ & 94,887 \\
\hline Good & $39 \%(8333)$ & $33 \%(78,502)$ & 86,835 \\
\hline Fair & $18 \%(3917)$ & $11 \%(26,950)$ & 30,867 \\
\hline Poor & $4 \%(821)$ & $2 \%(4817)$ & 5638 \\
\hline \multicolumn{4}{|l|}{ Self-rated quality of life } \\
\hline Excellent & $17 \%(3567)$ & $24 \%(56,330)$ & 59,897 \\
\hline Very good & $34 \%(7277)$ & $38 \%(86,841)$ & 94,118 \\
\hline Good & $34 \%(7120)$ & $28 \%(64,428)$ & 71,548 \\
\hline Fair & $13 \%(2744)$ & $9 \%(19,834)$ & 22,578 \\
\hline Poor & $2 \%(470)$ & $2 \%(3830)$ & 4300 \\
\hline
\end{tabular}

Percentages are out of column totals which include missing values: education (1.7\%), region of residence (1.9\%), country of birth ( $0.8 \%)$, BMI (6.6\%), physical activity (3.5\%), smoking status $(0.3 \%)$ and alcohol intake (2.1\%). Those with missing values for an outcome are excluded from the corresponding analyses: physical functioning limitations (13.3\%), psychological distress (K10 score, 11.4\%), self-rated health (3.5\%) and self-rated quality of life (5.3\%). There were no missing values in age or sex 


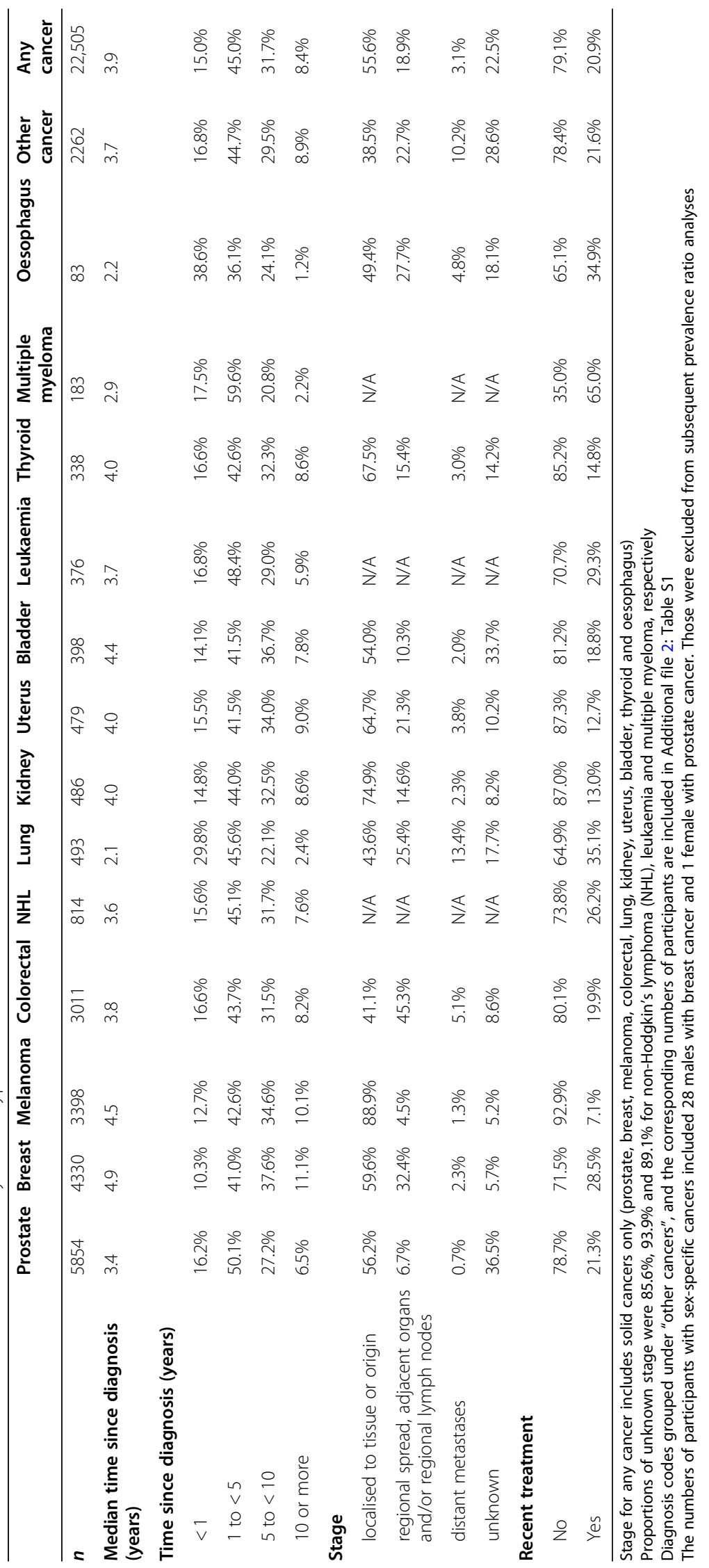




\begin{tabular}{|c|c|c|c|c|c|c|c|}
\hline \multicolumn{4}{|c|}{ a. Severe physical functioning limitations } & \multicolumn{4}{|c|}{ b. Moderate/High psychological distress } \\
\hline Type of cancer & $\%(n / N)$ & PR $(95 \% \mathrm{Cl})$ & & Type of cancer & $\%(\mathbf{n} / \mathbf{N})$ & PR $(95 \% \mathrm{Cl})$ & \\
\hline Multiple myeloma & $46.7(70 / 150)$ & $3.10(2.56-3.77)$ & $\rightarrow$ & Lung & $34.6(136 / 393)$ & $1.67(1.46-1.92)$ & * \\
\hline Lung & $48.5(189 / 390)$ & $2.81(2.50-3.15)$ & - & Multiple myeloma & $31.9(45 / 141)$ & $1.53(1.20-1.96)$ & $\rightarrow$ \\
\hline Kidney & $25.5(102 / 400)$ & $1.64(1.39-1.94)$ & - & $\mathrm{NHL}$ & $25.8(171 / 663)$ & $1.20(1.05-1.36)$ & - \\
\hline Oesophagus & $27.7(18 / 65)$ & $1.60(1.09-2.36)$ & $\rightarrow$ & Kidney & $24.1(100 / 414)$ & $1.17(0.98-1.38)$ & - \\
\hline $\mathrm{NHL}$ & $25.4(171 / 673)$ & $1.56(1.37-1.78)$ & - & Thyroid & $27.1(82 / 302)$ & $1.11(0.92-1.33)$ & - \\
\hline Uterus (female only) & $26.1(102 / 390)$ & $1.54(1.31-1.82)$ & - & Prostate (male only) & $20.1(991 / 4942)$ & $1.09(1.02-1.15)$ & - \\
\hline Leukaemia & $22.8(72 / 316)$ & $1.47(1.21-1.79)$ & $\rightarrow$ & Oesophagus & $20.9(14 / 67)$ & $1.06(0.67-1.68)$ & - \\
\hline Thyroid & $18.0(52 / 289)$ & $1.36(1.07-1.72)$ & - & Uterus (female only) & $24.8(99 / 400)$ & $1.05(0.88-1.24)$ & - \\
\hline Bladder & $27.6(91 / 330)$ & $1.34(1.12-1.59)$ & - & Leukaemia & $21.8(66 / 303)$ & $1.03(0.84-1.28)$ & $\rightarrow$ \\
\hline Breast (female only) & $19.7(721 / 3657)$ & $1.23(1.16-1.32)$ & - & Bladder & $19.7(60 / 304)$ & $1.03(0.82-1.29)$ & $\rightarrow$ \\
\hline Colorectal & $22.1(547 / 2476)$ & $1.20(1.12-1.29)$ & - & Colorectal & $19.7(477 / 2420)$ & $0.97(0.89-1.05)$ & - \\
\hline Prostate (male only) & $16.7(834 / 5003)$ & $1.11(1.04-1.19)$ & - & Melanoma & $20.6(609 / 2963)$ & $0.96(0.89-1.03)$ & - \\
\hline Melanoma & $15.9(471 / 2960)$ & $1.02(0.94-1.10)$ & - & Breast (female only) & $23.0(856 / 3718)$ & $0.95(0.90-1.01)$ & - \\
\hline Other cancer & $24.5(465 / 1900)$ & $1.57(1.46-1.70)$ & - & Other cancer & $26.8(502 / 1875)$ & $1.22(1.13-1.32)$ & - \\
\hline Any cancer & $20.6(3911 / 19025)$ & $1.28(1.25-1.32)$ & - & Any cancer & $22.2(4213 / 18933)$ & $1.05(1.02-1.08)$ & - \\
\hline No cancer & $12.6(26717 / 212030)$ & 1 & 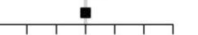 & No cancer & $23.5(51130 / 217282)$ & 1 & 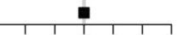 \\
\hline & & & $\begin{array}{llll}0.25 & 1.02 .0 & 4.0 & 8.0 \\
P R(95 \% & C l) \text { on log-scale }\end{array}$ & & & & 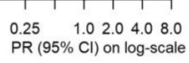 \\
\hline \multicolumn{4}{|c|}{ c: Poor/Fair self-rated health } & \multicolumn{4}{|c|}{ d: Poor/Fair self-rated quality of life } \\
\hline Type of cancer & $\%(\mathbf{n} / \mathrm{N})$ & PR $(95 \% \mathrm{Cl})$ & & Type of cancer & $\%(\mathbf{n} / \mathrm{N})$ & PR $(95 \% \mathrm{Cl})$ & \\
\hline Multiple myeloma & $48.2(81 / 168)$ & $3.11(2.64-3.66)$ & $*$ & Lung & $31.9(145 / 455)$ & $2.53(2.21-2.91)$ & * \\
\hline Lung & $46.5(216 / 465)$ & $2.81(2.54-3.12)$ & • & Multiple myeloma & $27.9(46 / 165)$ & $2.40(1.87-3.07)$ & $\rightarrow$ \\
\hline Leukaemia & $31.4(114 / 363)$ & $2.02(1.73-2.36)$ & - & $\mathrm{NHL}$ & $19.6(149 / 760)$ & $1.66(1.44-1.92)$ & - \\
\hline Oesophagus & $30.8(24 / 78)$ & $1.92(1.38-2.69)$ & $\rightarrow-$ & Leukaemia & $18.8(66 / 351)$ & $1.59(1.28-1.98)$ & $\rightarrow$ \\
\hline $\mathrm{NHL}$ & $29.6(229 / 775)$ & $1.91(1.71-2.13)$ & $\cdot$ & Kidney & $18.6(85 / 456)$ & $1.54(1.27-1.86)$ & - \\
\hline Kidney & $26.7(123 / 460)$ & $1.68(1.45-1.96)$ & - & Oesophagus & $18.7(14 / 75)$ & $1.53(0.96-2.45)$ & $\rightarrow$ \\
\hline Thyroid & $20.6(67 / 325)$ & $1.57(1.28-1.94)$ & $\rightarrow$ & Thyroid & $15.1(48 / 318)$ & $1.52(1.18-1.96)$ & $\rightarrow$ \\
\hline Uterus (female only) & $21.4(98 / 459)$ & $1.54(1.30-1.84)$ & - & Bladder & $19.9(73 / 366)$ & $1.39(1.13-1.71)$ & - \\
\hline Colorectal & $23.1(659 / 2859)$ & $1.39(1.30-1.49)$ & - & Uterus (female only) & $14.5(65 / 448)$ & $1.38(1.10-1.72)$ & $\rightarrow$ \\
\hline Bladder & $25.0(95 / 380)$ & $1.33(1.12-1.59)$ & - & Colorectal & $15.8(443 / 2803)$ & $1.25(1.14-1.36)$ & - \\
\hline Breast (female only) & $17.9(740 / 4132)$ & $1.33(1.24-1.42)$ & - & Prostate (male only) & $14.4(802 / 5554)$ & $1.15(1.08-1.23)$ & - \\
\hline Prostate (male only) & $20.5(1158 / 5643)$ & $1.24(1.17-1.31)$ & - & Breast (female only) & $11.8(480 / 4064)$ & $1.15(1.05-1.25)$ & - \\
\hline Melanoma & $15.5(509 / 3286)$ & $1.00(0.92-1.08)$ & - & Melanoma & $10.9(351 / 3232)$ & $0.92(0.83-1.01)$ & - \\
\hline Other cancer & $28.9(618 / 2142)$ & $1.87(1.75-2.00)$ & - & Other cancer & $21.1(443 / 2104)$ & $1.80(1.66-1.96)$ & - \\
\hline Any cancer & $22.0(4738 / 21562)$ & $1.41(1.37-1.45)$ & - & Any cancer & $15.2(3214 / 21178)$ & $1.28(1.24-1.32)$ & - \\
\hline \multirow[t]{2}{*}{ No cancer } & $13.5(31767 / 235530)$ & 1 & $=$ & No cancer & $10.2(23664 / 231263)$ & 1 & 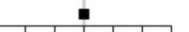 \\
\hline & & & $\begin{array}{llll}0.25 & 1.02 .0 & 4.08 .0 \\
P R(95 \% \mathrm{Cl}) \text { on log-scale }\end{array}$ & & & & $\begin{array}{llll}0.25 & 1.02 .0 & 4.0 & 8.0 \\
\text { PR } & (95 \% \mathrm{Cl}) \text { on log-scale }\end{array}$ \\
\hline
\end{tabular}

$(1.32,1.09-1.60)$ and no significant difference in the quality of life (1.01, 0.83-1.23; Fig. 5).

Worse physical functioning in those with compared to without cancer was observed in all of the demographic groups examined (Fig. 6) with the relation of cancer to severe physical functioning limitations much stronger in younger compared to older participants (Fig. 6, $p_{\text {interaction }}<0.0001$ ), in parallel with increasing levels of physical disability with age among those without cancer. The relationship of cancer to severe physical functioning limitations was stronger for women compared to men $\left(P_{\text {interaction }}<0.0001\right)$, for those outside of major cities compared to those living in major cities $\left(p_{\text {interaction }}=0.0014\right)$ and for those with university education compared to those without school certificate $\left(p_{\text {interaction }}<0.0001\right)$. No significant difference was observed according to whether or not participants were born in Australia or elsewhere.

The overall pattern of elevated prevalences of adverse person-centred outcomes in cancer survivors compared to cancer-free individuals was similar when outcomes of moderate/severe limitations (MOS-PF <90) and high distress $(22 \leq \mathrm{K}-10 \leq 50)$ were used (Additional file 2: Figs. S10-S11). When restricted to those without severe physical functioning limitations (Additional file 2: Fig.
S12), the broad patterns remained similar, with attenuated effect estimates. Further adjustment for educational attainment did not materially change patterns of adverse outcomes across joint categories cancer and physical disability limitations (Additional file 2: Table S2).

\section{Discussion}

In this large population-based study, compared to people without cancer, cancer survivors were more likely to report lower levels of physical functioning, self-rated health and quality of life and slightly higher psychological distress than those without cancer, with considerable variation across cancer types, time since diagnosis, treatments and stages.

Certain cancers such as lung cancer, multiple myeloma and the composite group of less common "other cancers" had the worst outcomes consistently across all the four measures investigated, while those with melanoma consistently reported similar levels to those without cancer across all outcome measures. The potential reasons for poor outcomes for some cancers include lower cure rate for some such as lung cancer (and thus ongoing symptoms related to cancer and its treatment), higher toxicity of treatment (such as bone marrow transplant commonly used in myeloma) and higher prevalence of 


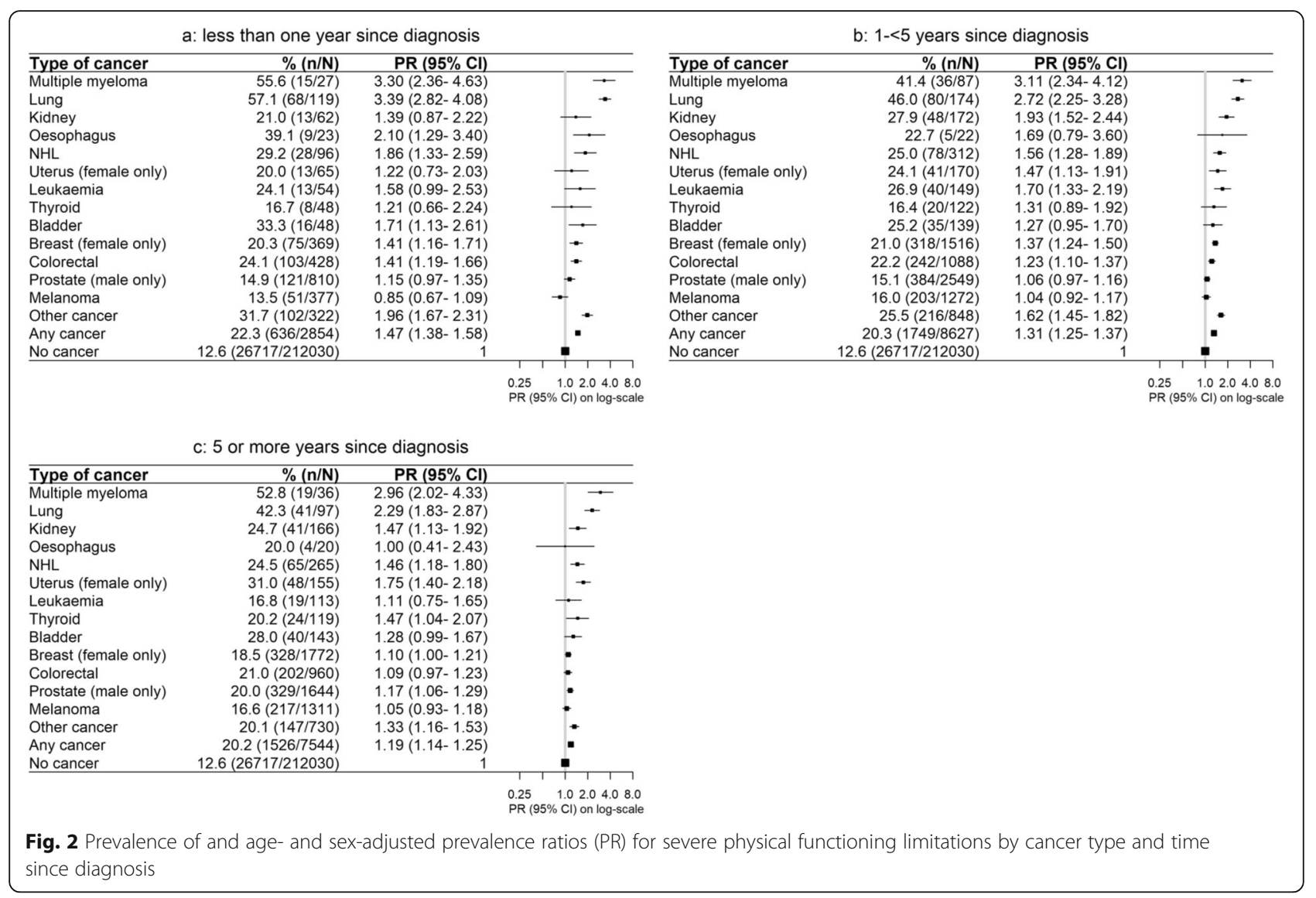

comorbid disease (as in lung cancer and myeloma). The "other" cancer group is a heterogeneous group of rarer cancers, often with a lack of proven treatment protocols and with a range of prognoses and treatments, including some which are intense and toxic.

There are a number of factors that contribute to the variability of outcomes. Although the 5-year relative survival for people diagnosed with cancer has been improving over the last 30 years in Australia, survival is less than 50\% for some cancer types such as multiple myeloma, mesothelioma, lung cancer, oesophagus cancer and pancreatic cancer. People diagnosed with these cancers are more likely to be living with incurable/metastatic cancer which adds to disability and emotional distress. Smoking, a key risk factor for many of these cancers, is also associated with other chronic conditions such as cardiovascular disease; living with multimorbidity adds to disability burden. This is also true for cancers with a higher incidence in older age groups (e.g. prostate cancer); despite improvements in screening and early detection, the burden of comorbid conditions at diagnosis is likely to contribute to poorer health and functioning. The favourable outcomes for melanoma may be explained by an earlier stage at diagnosis and relatively brief localised surgical treatment for the majority of cases.
Adverse person-centred outcomes attenuated with increasing time since diagnosis and for those with localised/unknown cancer stage and no recent treatment compared to others; psychological distress was not elevated among survivors five or more years post-diagnosis, with localised disease or without recent treatment. Overall, compared to those without cancer, cancer survivors had a significantly higher prevalence of physical functioning limitations in all of the population subgroups examined. Psychological distress and quality of life were much more strongly related to physical disability than to cancer diagnosis itself, with similar outcomes in cancer survivors and those without cancer, among people without physical disability. These are the first large-scale analyses, to our knowledge, to consider the relationship of cancer to psychological distress among people with and without physical disability, apart from the findings from an earlier subset of data from the 45 and Up Study [22]. The findings are broadly consistent with previous general studies on the importance of disability and physical morbidity in mental health [13] and evidence of increased distress with reduced physical functioning among women with breast cancer [23].

This is the most comprehensive study of personcentred outcomes across different cancer types, to our 


\begin{tabular}{|c|c|c|c|c|c|c|c|}
\hline \multicolumn{4}{|c|}{ a: localised to tissue } & \multicolumn{4}{|c|}{ b: regional spread } \\
\hline Types of cancer & $\%(\mathbf{n} / \mathbf{N})$ & PR $(95 \% \mathrm{Cl})$ & & Types of cancer & $\%(n / N)$ & PR $(95 \% \mathrm{Cl})$ & \\
\hline Lung & $43.2(76 / 176)$ & $2.45(2.04-2.93)$ & - & Lung & 49.5 (49/99) & $3.28(2.59-4.17)$ & $\rightarrow$ \\
\hline Kidney & $25.5(77 / 302)$ & $1.63(1.35-1.97)$ & + & Kidney & $31.6(18 / 57)$ & $1.98(1.33-2.95)$ & $\rightarrow$ \\
\hline Oesophagus & $32.4(11 / 34)$ & $1.89(1.18-3.03)$ & $\rightarrow$ & Oesophagus & $15.8(3 / 19)$ & $1.06(0.35-3.17)$ & — \\
\hline Uterus (female only) & $26.0(65 / 250)$ & $1.54(1.26-1.88)$ & - & Uterus (female only) & $30.0(24 / 80)$ & $1.66(1.18-2.34)$ & $\rightarrow$ \\
\hline Thyroid & $17.4(34 / 196)$ & $1.33(0.98-1.80)$ & - & Thyroid & $13.6(6 / 44)$ & $1.17(0.57-2.40)$ & - \\
\hline Bladder & $24.6(44 / 179)$ & $1.17(0.91-1.51)$ & - & Bladder & $26.5(9 / 34)$ & $1.46(0.80-2.69)$ & - \\
\hline Breast (female only) & $17.8(390 / 2196)$ & $1.09(1.00-1.19)$ & . & Breast (female only) & $20.9(248 / 1187)$ & $1.41(1.26-1.57)$ & - \\
\hline Colorectal & $20.8(209 / 1006)$ & $1.10(0.98-1.24)$ & - & Colorectal & $22.2(249 / 1122)$ & $1.22(1.10-1.36)$ & - \\
\hline Prostate (male only) & $13.9(398 / 2870)$ & $1.00(0.91-1.10)$ & - & Prostate (male only) & $11.8(41 / 347)$ & $0.95(0.72-1.27)$ & $\leftarrow$ \\
\hline Melanoma & $15.2(402 / 2640)$ & $0.98(0.90-1.07)$ & - & Melanoma & $25.2(32 / 127)$ & $1.48(1.09-1.99)$ & $\rightarrow$ \\
\hline Other solid cancer & $20.8(149 / 716)$ & $1.39(1.21-1.60)$ & - & Other solid cancer & $21.1(89 / 422)$ & $1.43(1.18-1.72)$ & - \\
\hline Any solid cancer & $17.6(1860 / 10580)$ & $1.12(1.08-1.17)$ & - & Any solid cancer & $21.7(769 / 3547)$ & $1.38(1.29-1.47)$ & - \\
\hline No cancer & $12.6(26717 / 212030)$ & 1 & - & No cancer & $12.6(26717 / 212030)$ & 1 & - \\
\hline \multicolumn{4}{|r|}{ 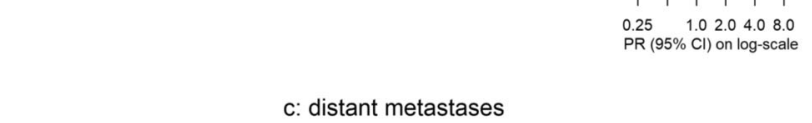 } & \multicolumn{4}{|r|}{ 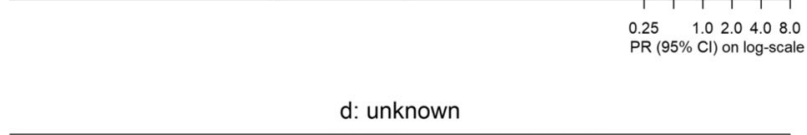 } \\
\hline \multicolumn{4}{|c|}{ c: distant metastases } & \multicolumn{4}{|c|}{ d: unknown } \\
\hline \multicolumn{4}{|l|}{ Types of cancer } & \multirow{2}{*}{\multicolumn{2}{|c|}{$\begin{array}{l}\text { Types of cancer } \\
\text { Lung }\end{array}$}} & $\mathrm{PR}(95 \% \mathrm{Cl})$ & \multirow{2}{*}{$\rightarrow$} \\
\hline Lung & $69.2(36 / 52)$ & $4.10(3.22-5.21)$ & $\leftarrow$ & & & $2.22(1.67-2.95)$ & \\
\hline Kidney & $30.0(3 / 10)$ & $3.37(1.28-8.90)$ & $\longrightarrow$ & Kidney & $12.9(4 / 31)$ & $0.84(0.36-1.96)$ & - \\
\hline Oesophagus & $33.3(1 / 3)$ & $3.14(0.44-22.58)$ & $\longrightarrow$ & Oesophagus & $33.3(3 / 9)$ & $1.31(0.57-3.00)$ & - \\
\hline Uterus (female only) & $33.3(5 / 15)$ & $2.34(1.07-5.11)$ & $-\ldots$ & Uterus (female only) & $17.8(8 / 45)$ & $1.12(0.60-2.09)$ & - \\
\hline Thyroid & $22.2(2 / 9)$ & $1.11(0.45-2.75)$ & - & Thyroid & $25.0(10 / 40)$ & $1.75(1.11-2.77)$ & $\rightarrow$ \\
\hline Bladder & $85.7(6 / 7)$ & $6.40(3.93-10.45)$ & $\rightarrow$ & Bladder & $29.1(32 / 110)$ & $1.36(1.01-1.82)$ & - \\
\hline Breast (female only) & $29.3(24 / 82)$ & $2.19(1.55-3.08)$ & $\rightarrow$ & Breast (female only) & 30.7 (59/192) & $1.52(1.26-1.83)$ & - \\
\hline Colorectal & $32.1(44 / 137)$ & $1.91(1.50-2.42)$ & - & Colorectal & $21.3(45 / 211)$ & $1.18(0.93-1.50)$ & - \\
\hline Prostate (male only) & $38.5(15 / 39)$ & $2.38(1.50-3.77)$ & $\rightarrow$ & Prostate (male only) & $21.8(380 / 1747)$ & $1.26(1.15-1.38)$ & - \\
\hline Melanoma & $17.9(7 / 39)$ & $1.14(0.57-2.29)$ & - & Melanoma & $19.5(30 / 154)$ & $1.25(0.92-1.69)$ & -. \\
\hline Other solid cancer & $32.6(62 / 190)$ & $2.02(1.63-2.50)$ & - & Other solid cancer & $26.7(97 / 363)$ & $1.66(1.41-1.97)$ & - \\
\hline Any solid cancer & $35.2(205 / 583)$ & $2.23(1.98-2.50)$ & . & Any solid cancer & $23.5(696 / 2967)$ & $1.32(1.24-1.41)$ & - \\
\hline No cancer & $12.6(26717 / 212030)$ & 1 & - & No cancer & $12.6(26717 / 212030)$ & 1 & - \\
\hline & & & $\begin{array}{l}0.25 \\
0.02 \\
P R(95 \% \mathrm{Cl}) \text { on log-scale }\end{array}$ & & & & 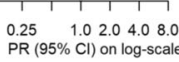 \\
\hline
\end{tabular}

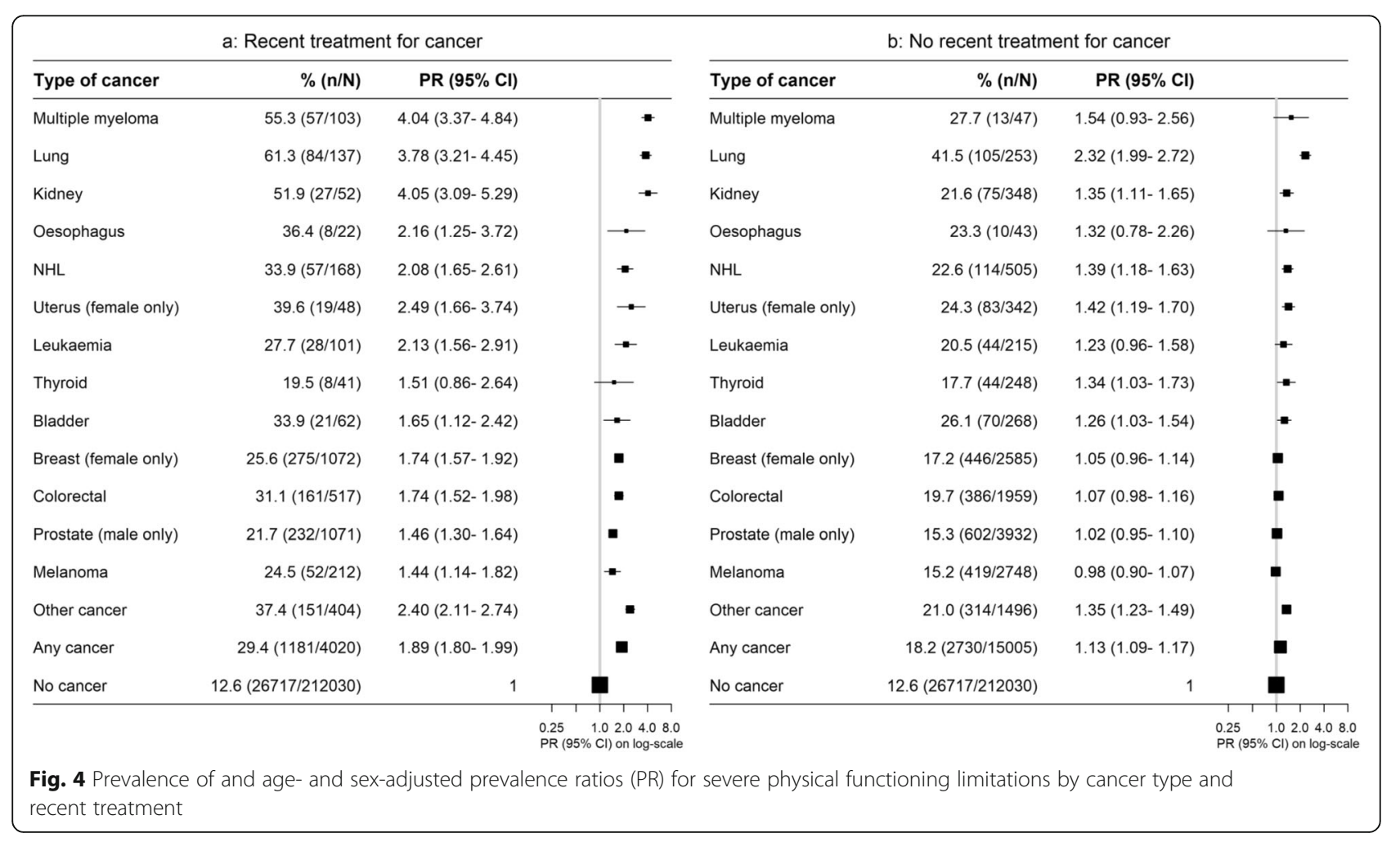




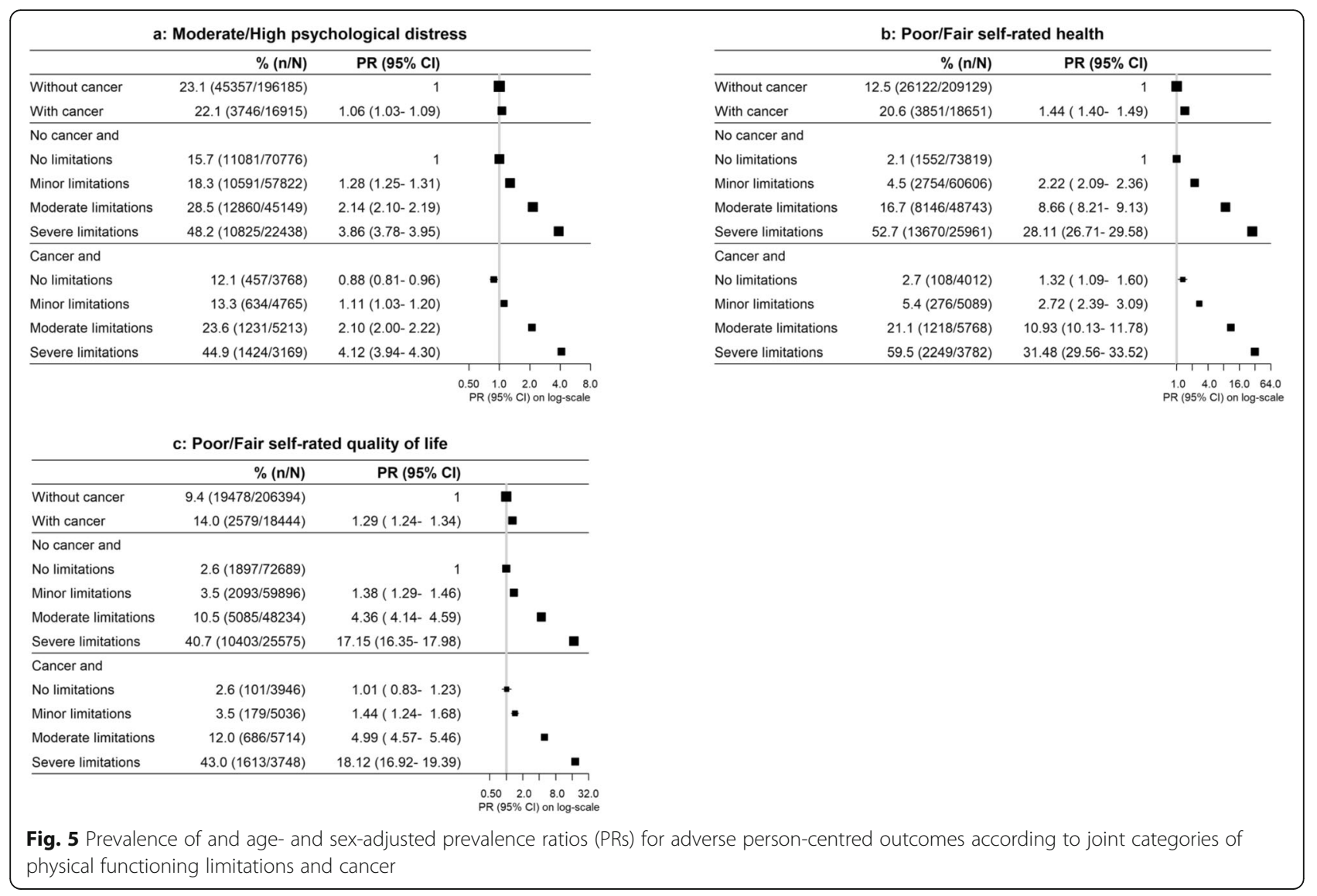

knowledge, considering multiple person-centred outcomes in the full range of common cancers and many less common cancer types, permitting comparisons across types and outcomes, including according to clinical factors and in different population subgroups. Previous studies have varied in terms of outcome measures used, study design, characteristics of cancer survivors and selection of controls; most have focused on single common cancer types such as breast and prostate cancer. Of the 104 studies identified, 29 studies [6-12, 22, 24-46] examined person-centred outcomes among survivors of different cancer types, and 75 studies [5, 23, 47-120] analysed survivors of a single cancer type (Additional file 3). In general, these studies have shown reduced physical functioning in cancer survivors compared to people without cancer and, where such data have been available, have also found variation according to cancer type and clinical characteristics. The likelihood of poor health and disability has also been shown to be higher among cancer survivors reporting comorbid chronic conditions [10]. Studies on mental health outcomes in those with versus without cancer have found comparable [7] to moderately elevated [22] adverse mental health outcomes in those with versus without cancer overall and a significantly higher likelihood of adverse outcomes for some rarer cancers [80]. Quality of life and self-rated health vary depending on the cancer type, but outcomes for long-term survivors generally approximate those of people without cancer. Limited evidence shows that person-centred outcomes vary according to time since diagnosis [121], therapeutic regimen [122], comorbidity [29] and cultural background [123].

This study was conducted using data from a large population-based study, with cancer diagnoses sourced from linked cancer registry data. The study questionnaire used validated measures of physical functioning limitations, psychological distress and self-rated health and a basic measure of quality of life. As in other cohort studies, the overall response rate to the baseline survey was modest (18\%), and absolute prevalences in this cohort study may not be representative of the Australian population. However, cohort studies do not need to be representative to produce effect estimates-such as prevalence ratios-that are generalisable [124], and internal comparisons within cohort studies are generally reliable [125]. The study compares adverse personcentred outcomes in community-dwelling individuals with and without cancer. Although the possibility that some adverse outcomes could have been present before 


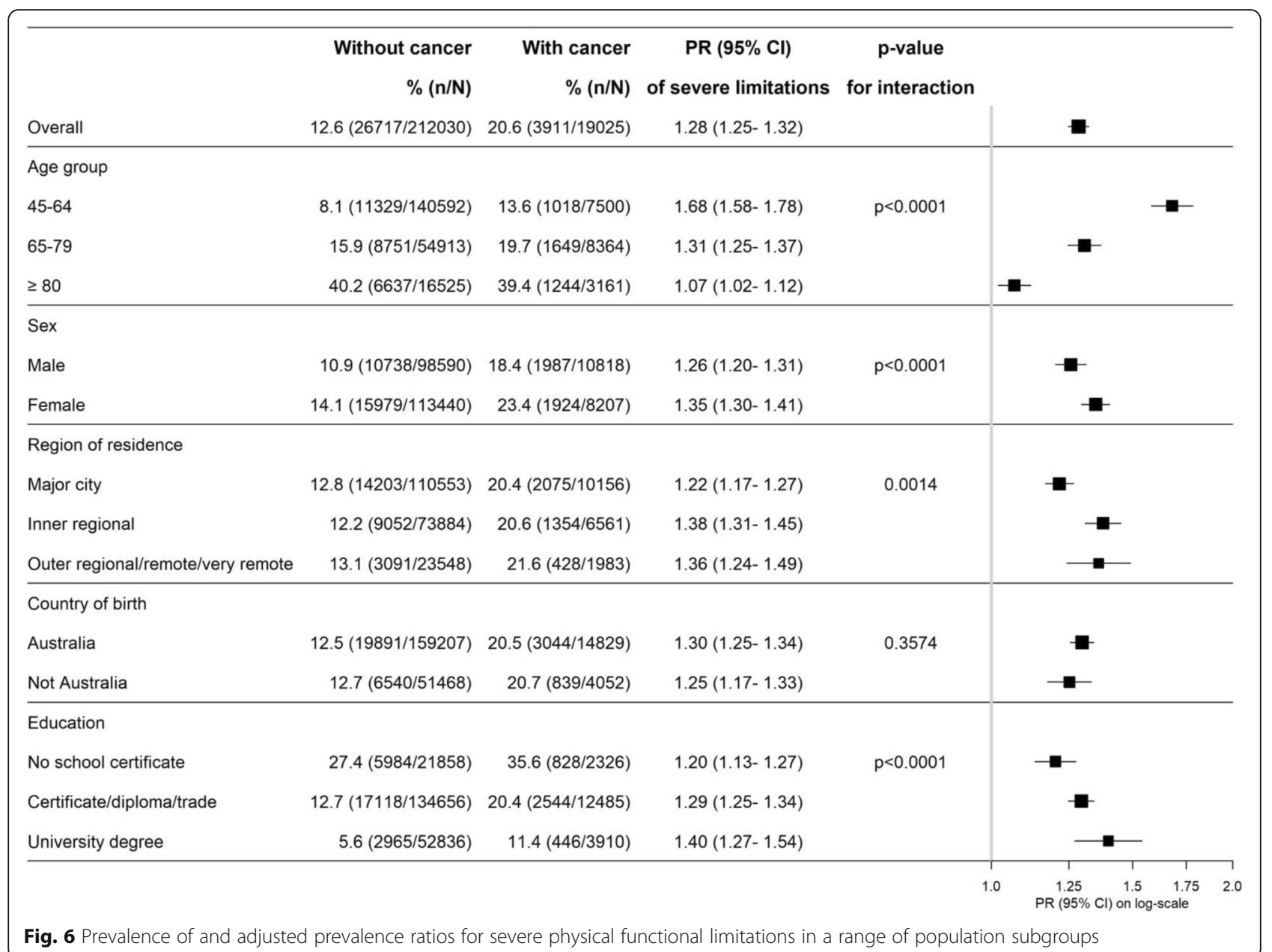

the onset of cancer cannot be excluded, it is not directly relevant to this comparison.

\section{Conclusions}

The findings demonstrate the impact of and great variation in person-centred outcomes throughout the cancer journey and according to cancer type. They show the centrality of physical disability in relation to a person's mental health and quality of life, both with and without cancer, and the need to support physical functioning, including by focusing on non-cancer morbidity [126]. These, in turn, emphasise the importance of holistic, integrated health-including by non-cancer providers such as general practitioners-in delivering the diversity of care required to optimise survivorship outcomes.

This study shows that physical disability is likely to be a key driver of psychological distress and reduced quality of life. In addition to routine screening for psychological distress [127], management of physical functioning and other symptoms is important in cancer survivorship. The positive long-term outcomes for breast cancer, even in the presence of physical disability, provide foundations for support and interventions for other cancer types. The study also shows the value of data on person-centred outcomes for quantifying cancer outcomes, in addition to standard measures such as mortality and health services use, including providing evidence to support planning and improvements in the provision of care. Ideally, assessment of person-centred outcomes including physical impairment should be part of the routine clinical assessment of cancer survivors at key time points such as completion of treatment and routine follow-up visits. The Model of Cancer Survivorship Care [128] recommended by the Clinical Oncology Society of Australia recognises this, but such assessment has not yet been adopted into routine clinical practice.

The evidence from this paper is also likely to be of use to cancer survivors and those supporting them, particularly in informing broad expectations for the cancer journey. The data highlight greater vulnerability and support needs around the time of diagnosis and treatment, with advanced disease and specific cancer types. They also provide reassurance that, for the majority of cancer types, mental health and quality of life in longer- 
term survivors do not differ markedly from that in people without cancer. This mirrors qualitative studies which demonstrate that after an adjustment period, many cancer survivors report that they are coping well, are managing and adapting to any ongoing symptoms/ side effects and have found a "new normal" $[129,130]$. Although access to specific survivorship care services within the Australian health care system is limited and variable, as is the case in most countries around the world [131], cancer survivors are able to draw on universal primary, secondary and tertiary care in Australia. Such care is likely to contribute in general terms to outcomes in survivors, although shortfalls in these services have been noted.

There is a need to consider the diversity of cancers, including less common ones and those with poor survival, when investigating contributors to poor physical function and identifying targets for intervention; these contributors and targets are likely to include cancer progression, risk factors and treatment, as well as comorbid conditions, contextual factors and life circumstances.

\section{Supplementary Information}

Supplementary information accompanies this paper at https://doi.org/10. 1186/s12916-020-01830-4.

Additional file 1. : Brief Summary of Consumer Engagement Plan.

Additional file 2: Table S1. Number of cases grouped under "other" cancers. Table S2. Prevalence of and age-, sex- and education- adjusted prevalence ratios (PRs) for adverse person-centred outcomes according to joint categories of physical functioning limitations and cancer. Figure S1. Prevalence of moderate/high distress by cancer type and time since diagnosis. Figure S2. Prevalence of moderate/high distress by cancer type and stage. Figure S3. Prevalence of moderate/high distress by cancer type and recent treatment. Figure S4. Prevalence of poor/fair selfrated health by cancer type and time since diagnosis; Figure S5. Prevalence of poor/fair self-rated health by cancer type and stage. Figure S6. Prevalence of poor/fair self-rated health by cancer type and recent treatment; Figure S7. Prevalence of poor/fair self-rated quality of life by cancer type and time since diagnosis. Figure S8. Prevalence of poor/fair self-rated quality of life by cancer type and stage. Figure S9. Prevalence of poor/fair self-rated quality of life by cancer type and recent treatment. Figure S10. Prevalence of high psychological distress by cancer type. Figure S11. Prevalence of moderate/severe physical functioning limitations by cancer type. Figure S12. Prevalence of and age- and sex- adjusted prevalence ratios (PR) for adverse person-centred outcomes by cancer type: analyses restricted to those without severe physical functioning limitations.

Additional file 3. : Brief review of person-centred outcomes and cancer.

\section{Acknowledgements}

This study uses data from the 45 and Up Study, which is managed by the Sax Institute in collaboration with major partner Cancer Council NSW, and the following partners: the National Heart Foundation of Australia (NSW Division); NSW Ministry of Health; NSW Government Family \& Community Services-Ageing, Carers and the Disability Council NSW; and the Australian Red Cross Blood Service. We thank the many thousands of people participating in the 45 and Up Study. This study is funded by the National Health and Medical Research Council of Australia (NHMRC) Project Grant (reference:1139539). Professor Emily Banks is supported by the NHMRC (reference:1136128).

\section{Authors' contributions}

EB and GJ conceived the idea for the study and, along with JT, designed the analyses. JT conducted the statistical analyses. JS and LB provided consumer input. AY conducted the literature search. GJ, JT and EB drafted the initial version of the manuscript. All authors contributed to the review of the analysis plan, interpretation of the results and revision of the manuscript and agreed to submit the final version for publication.

\section{Funding}

This research was supported by the National Health and Medical Research Council (NHMRC) of Australia.

\section{Availability of data and materials}

Data supporting the findings from this study are available from the Sax Institute, the NSW Department of Health and the Australian Bureau of Statistics, with data linkage conducted by the NSW Centre for Health Record Linkage. Restrictions apply to the availability of these data, which were used under licence for the current study, and so are not publicly available. Data are however available from the authors upon reasonable request and with permission from the Sax Institute (www.saxinstitute.org.au) and the NSW Department of Health

\section{Ethics approval and consent to participate}

Ethical approval for the conduct of the 45 and Up Study was provided by the University of New South Wales Human Research Ethics Committee. Participants joined the study providing informed consent for follow-up through repeated data collection and linkage of their data to population health databases. Ethical approval for the present analysis was provided by the NSW Population \& Health Services Research Ethics Committee (12/CIPHS/ 31) and the Australian National University Human Research Ethics Committee (2012/504).

\section{Consent for publication}

Not applicable

\section{Competing interests}

$\mathrm{KC}$ is a co-principal investigator of an unrelated investigator-initiated trial of cervical screening in Australia (Compass; ACTRN12613001207707 and NCT02328872), which is conducted and funded by the VCS Foundation. The VCS Foundation received equipment and a funding contribution from Roche Molecular Systems, USA. However, neither KC nor her institution on her behalf (Cancer Council NSW) receives direct funding from the industry for this trial or any other project. EB reports grants from NHMRC of Australia, during the conduct of the study. All other authors declare no other conflict of interest.

\section{Author details}

${ }^{1}$ National Centre for Epidemiology and Population Health, Research School of Population Health, Australian National University, Mills Road, Acton, Canberra, ACT 2601, Australia. ${ }^{2}$ Flinders University and Flinders Medical Centre, Adelaide, SA, Australia. ${ }^{3}$ Centre for Medical Psychology and Evidence-based Medicine, School of Psychology, Faculty of Science, The University of Sydney, Sydney, NSW, Australia. ${ }^{4}$ Cancer Research Division, Cancer Council New South Wales, Kings Cross, NSW, Australia. ${ }^{5}$ Prince of Wales Clinical School, University of New South Wales, Sydney, NSW, Australia. ${ }^{6}$ CanSpeak Australia, Sydney, NSW, Australia. ${ }^{7}$ Primary Care Collaborative Cancer Clinical Trials Group Community Advisory Group, Melbourne, VIC, Australia. ${ }^{8}$ Psycho-oncology Cooperative Research Group Community Advisory Group, Camperdown, NSW, Australia. ' $5 a x$ Institute, Haymarket, NSW, Australia.

Received: 18 August 2020 Accepted: 27 October 2020

Published online: 01 December 2020

\section{References}

1. Institute of Medicine and National Research Council. From cancer patient to cancer survivor: lost in transition. Washington, DC: The National Academies Press; 2006.

2. Jefford M. Improving outcomes for cancer survivors in Australia. Cancer Forum. 2009;33(3):159-63. 
3. Hodgkinson K, Butow P, Hunt GE, Pendlebury S, Hobbs KM, Wain G. Breast cancer survivors' supportive care needs 2-10 years after diagnosis. Support Care Cancer. 2007;15(5):515-23.

4. Laidsaar-Powell R, Konings S, Rankin N, Koczwara B, Kemp E, Mazariego C, et al. A meta-review of qualitative research on adult cancer survivors: current strengths and evidence gaps. J Cancer Surviv. 2019;13(6):852-89.

5. Mols F, Vingerhoets AJJM, Coebergh JW, van de Poll-Franse LV. Quality of life among long-term breast cancer survivors: a systematic review. Eur J Cancer. 2005:41(17):2613-9.

6. Foster C, Wright D, Hill H, Hopkinson J, Roffe L. Psychosocial implications of living 5 years or more following a cancer diagnosis: a systematic review of the research evidence. Eur J Cancer Care. 2009;18(3):223-47.

7. Kent EE, Ambs A, Mitchell SA, Clauser SB, Smith AW, Hays RD. Health-related quality of life in older adult survivors of selected cancers: data from the SEER-MHOS linkage. Cancer. 2015:121(5):758-65.

8. Baker F, Denniston M, Haffer SC, Liberatos P. Change in health-related quality of life of newly diagnosed cancer patients, cancer survivors, and controls. Cancer. 2009;115(13):3024-33.

9. Schootman M, Aft R, Jeffe DB. An evaluation of lower-body functional limitations among long-term survivors of 11 different types of cancers. Cancer. 2009;115(22):5329-38.

10. Hewitt M, Rowland JH, Yancik R. Cancer survivors in the United States: age health, and disability. J Gerontol Ser A Biol Med Sci. 2003;58(1):M82-91.

11. LeMasters T, Madhavan S, Sambamoorthi U, Kurian S. A population-based study comparing HRQOL among breast, prostate, and colorectal cancer survivors to propensity score matched controls, by cancer type, and gender Psychooncology. 2013;22(10):2270-82.

12. Glaser AW, Fraser LK, Corner J, Feltbower R, Morris EJ, Hartwell G, et al. Patient-reported outcomes of cancer survivors in England 1-5 years after diagnosis: a cross-sectional survey. BMJ Open. 2013;3(4):e002317.

13. Prince M, Patel V, Saxena S, Maj M, Maselko J, Phillips MR, et al. No health without mental health. Lancet. 2007:370(9590):859-77.

14. Banks E, Redman S, Jorm L, Armstrong B, Bauman A, Beard J, et al. Cohort profile: the 45 and up study. Int J Epidemiol. 2008;37(5):941-7.

15. Quality Assurance: Centre for Health Record Linkage (CHeReL); 2012 Available from: http://www.cherel.org.au/quality-assurance.

16. Australian Institute of Health and Welfare 2019. Cancer in Australia 2019. Cancer series no.119. Cat. no. CAN 123. Canberra: AlHW.

17. Stewart AL. Measuring functioning and well-being: the medical outcomes study approach. Durham and London: Duke University Press; 1992.

18. Haley SM, McHorney CA, Ware JE. Evaluation of the mos SF-36 physical functioning scale (PF-10): I. Unidimensionality and reproducibility of the Rasch item scale. J Clin Epidemiol. 1994;47(6):671-84.

19. Stewart A, Kamberg CJ. Physical functioning measures. In: Stewart A, Ware $J E$, editors. Measuring functioning and well-being: the medical outcomes study approach. Durham: Duke University Press; 1992

20. Kessler RC, Andrews G, Colpe L, Hiripi E, Mroczek DK, Normand SL, et al. Short screening scales to monitor population prevalences and trends in non-specific psychological distress. Psychol Med. 2002;32(6):959-76.

21. Andrews G, Slade T. Interpreting scores on the Kessler Psychological Distress Scale (K10). Aust N Z J Public Health. 2001:25(6):494-7.

22. Banks E, Byles JE, Gibson RE, Rodgers B, Latz IK, Robinson IA, et al. Is psychological distress in people living with cancer related to the fact of diagnosis, current treatment or level of disability? Findings from a large Australian study. Med J Aust. 2010;193(5 Suppl):S62-7.

23. Syrowatka A, Motulsky A, Kurteva S, Hanley JA, Dixon WG, Meguerditchian AN, et al. Predictors of distress in female breast cancer survivors: a systematic review. Breast Cancer Res Treat. 2017;165(2):229-45.

24. Boyes AW, Girgis A, D'Este C, Zucca AC. Flourishing or floundering? Prevalence and correlates of anxiety and depression among a populationbased sample of adult cancer survivors 6 months after diagnosis. J Affect Disord. 2011;135(1):184-92.

25. Boyes AW, Girgis A, Zucca AC, Lecathelinais C. Anxiety and depression among long-term survivors of cancer in Australia: results of a populationbased survey. Med J Aust. 2009;190(S7):S94-S8.

26. Brown JC, Harhay MO, Harhay MN. Patient-reported versus objectivelymeasured physical function and mortality risk among cancer survivors. J Geriatr Oncol. 2016;7(2):108-15.

27. Eakin EG, Youlden DR, Baade PD, Lawler SP, Reeves MM, Heyworth JS, et al Health status of long-term cancer survivors: results from an Australian population-based sample. Cancer Epidemiol Biomarkers Prev. 2006;15(10):1969.
28. Elliott J, Fallows A, Staetsky L, Smith PWF, Foster CL, Maher EJ, et al. The health and well-being of cancer survivors in the UK: findings from a population-based survey. Br J Cancer. 2011;105(1):S11-20.

29. Garman KS, Pieper CF, Seo P, Cohen HJ. Function in elderly cancer survivors depends on comorbidities. J Gerontol Ser A. 2003;58(12):M1119-M24.

30. Götze H, Taubenheim S, Dietz A, Lordick F, Mehnert A. Comorbid conditions and health-related quality of life in long-term cancer survivors-associations with demographic and medical characteristics. J Cancer Surviv. 2018;12(5): 712-20.

31. Heins MJ, Korevaar JC, Hopman PEPC, Donker GA, Schellevis FG, Rijken MPM. Health-related quality of life and health care use in cancer survivors compared with patients with chronic diseases. Cancer. 2016;122(6):962-70.

32. Hoffman KE, McCarthy EP, Recklitis CJ, Ng AK. Psychological distress in longterm survivors of adult-onset cancer: results from a national survey. Arch Intern Med. 2009:169(14):1274-81.

33. Jefford M, Ward AC, Lisy K, Lacey K, Emery JD, Glaser AW, et al. Patientreported outcomes in cancer survivors: a population-wide cross-sectional study. Support Care Cancer. 2017;25(10):3171-9.

34. Keating NL, Nørredam M, Landrum MB, Huskamp HA, Meara E. Physical and mental health status of older long-term cancer survivors. J Am Geriatr Soc. 2005:53(12):2145-52.

35. Kim KH, Cho YY, Shin DW, Lee JH, Ko Y-J, Park SM. Comparison of physical and mental health status between cancer survivors and the general population: a Korean population-based survey (KNHANES II-IV). Support Care Cancer. 2013;21(12):3471-81

36. Lazovich D, Robien K, Cutler G, Virnig B, Sweeney C. Quality of life in a prospective cohort of elderly women with and without cancer. Cancer. 2009:115(S18):4283-97.

37. Leach CR, Bellizzi KM, Hurria A, Reeve BB. Is it my cancer or am i just getting older?: impact of cancer on age-related health conditions of older cancer survivors. Cancer. 2016;122(12):1946-53.

38. Mols F, Coebergh JWW, van de Poll-Franse LV. Health-related quality of life and health care utilisation among older long-term cancer survivors: a population-based study. Eur J Cancer. 2007:43(15):2211-21.

39. Ness KK, Wall MM, Oakes JM, Robison LL, Gurney JG. Physical performance limitations and participation restrictions among cancer survivors: a population-based study. Ann Epidemiol. 2006;16(3):197-205.

40. Ng HS, Roder D, Koczwara B, Vitry A. Comorbidity, physical and mental health among cancer patients and survivors: an Australian population-based study. Asia Pac J Clin Oncol. 2018;14(2):e181-e92.

41. Schroevers M, Ranchor AV, Sanderman R. Adjustment to cancer in the 8 years following diagnosis: a longitudinal study comparing cancer survivors with healthy individuals. Soc Sci Med. 2006;63(3):598-610.

42. Sweeney C, Schmitz KH, Lazovich D, Virnig BA, Wallace RB, Folsom AR. Functional limitations in elderly female cancer survivors. J Natl Cancer Inst. 2006;98(8):521-9.

43. Weaver KE, Forsythe LP, Reeve BB, Alfano CM, Rodriguez JL, Sabatino SA, et al. Mental and physical health-related quality of life among U.S. cancer survivors: population estimates from the 2010 National Health Interview Survey. Cancer Epidemiol Biomarkers Prev. 2012;21(11):2108.

44. Wikman A, Djärv $T$, Johar A, Lagergren P. Health-related quality of life does not differ between short-term, long-term and very long-term cancer survivors in the Swedish general population. Psycho-Oncology. 2013;22(6): 1369-74.

45. Zhao G, Li C, Li J, Balluz LS. Physical activity, psychological distress, and receipt of mental healthcare services among cancer survivors. J Cancer Surviv. 2013;7(1):131-9.

46. Zhao G, Okoro CA, Li J, White A, Dhingra S, Li C. Current depression among adult cancer survivors: findings from the 2010 Behavioral Risk Factor Surveillance System. Cancer Epidemiol. 2014;38(6):757-64

47. Alibhai SM, Leach M, Kermalli H, Gupta V, Kowgier ME, Tomlinson GA, et al. The impact of acute myeloid leukemia and its treatment on quality of life and functional status in older adults. Crit Rev Oncol Hematol. 2007:64(1):19-30.

48. Anastasiadis AG, Davis AR, Sawczuk IS, Fleming M, Perelman MA, Burchardt $M$, et al. Quality of life aspects in kidney cancer patients: data from a national registry. Support Care Cancer. 2003;11(11):700-6.

49. Andrykowski MA, Bishop MM, Hahn EA, Cella DF, Beaumont JL, Brady MJ, et al. Long-term health-related quality of life, growth, and spiritual wellbeing after hematopoietic stem-cell transplantation. J Clin Oncol. 2005;23(3): 599-608. 
50. Beisland C, Beisland E, Hjelle KM, Bostad L, Hjermstad MJ, Aarstad AKH, et al. Health-related quality of life in long-term survivors after renal cancer treatment. Scand J Urol. 2014;48(1):52-64.

51. Bellizzi KM, Rowland JH, Arora NK, Hamilton AS, Miller MF, Aziz NM. Physical activity and quality of life in adult survivors of non-Hodgkin's lymphoma. J Clin Oncol. 2009;27(6):960.

52. Beutel ME, Fischbeck S, Binder $H$, Blettner M, Brähler E, Emrich $K$, et al. Depression, anxiety and quality of life in long-term survivors of malignant melanoma: a register-based cohort study. PLoS One. 2015;10(1):e0116440. https://doi.org/10.1371/journal.pone.0116440.

53. Blaes $\mathrm{AH}, \mathrm{Ma} \mathrm{L}$, Zhang $\mathrm{Y}$, Peterson BA. Quality of life appears similar between survivors of indolent and aggressive non-Hodgkin lymphoma. Leuk Lymphoma. 2011;52(11):2105-10.

54. Bloom JR, Stewart SL, Chang S, Banks PJ. Then and now: quality of life of young breast cancer survivors. Psychooncology. 2004;13(3):147-60.

55. Brown JC, Lin LL, Segal S, Chu CS, Haggerty AE, Ko EM, et al. Physical activity, daily walking, and lower limb lymphedema associate with physical function among uterine cancer survivors. Support Care Cancer. 2014;22(11): 3017-25.

56. Caravati-Jouvenceaux A, Launoy G, Klein D, Henry-Amar M, Abeilard E, Danzon A, et al. Health-related quality of life among long-term survivors of colorectal cancer: a population-based study. Oncologist. 2011;16(11):162636.

57. Chambers SK, Meng X, Youl P, Aitken J, Dunn J, Baade P. A five-year prospective study of quality of life after colorectal cancer. Qual Life Res. 2012;21(9):1551-64.

58. Clark PE, Schover LR, Uzzo RG, Hafez KS, Rybicki LA, Novick AC. Quality of life and psychological adaptation after surgical treatment for localized renal cell carcinoma: impact of the amount of remaining renal tissue. Urology. 2001;57(2):252-6.

59. DiSipio T, Hayes S, Newman B, Janda M. Health-related quality of life 18 months after breast cancer: comparison with the general population of Queensland, Australia. Support Care Cancer. 2008;16(10):1141-50.

60. Djärv T, Lagergren J, Blazeby JM, Lagergren P. Long-term health-related quality of life following surgery for oesophageal cancer. Br J Surg. 2008; 95(9):1121-6.

61. Downing A, Morris EJ, Richards M, Corner J, Wright P, Sebag-Montefiore D, et al. Health-related quality of life after colorectal cancer in England: a patient-reported outcomes study of individuals 12 to 36 months after diagnosis. J Clin Oncol. 2015;33(6):616-24.

62. Egberts J-H, Schniewind B, Bestmann B, Schafmayer C, Egberts F, Faendrich $F$, et al. Impact of the site of anastomosis after oncologic esophagectomy on quality of life-a prospective, longitudinal outcome study. Ann Surg Oncol. 2008;15(2):566-75.

63. Ferrandina G, Petrillo M, Mantegna G, Fuoco G, Terzano S, Venditti L, et al. Evaluation of quality of life and emotional distress in endometrial cancer patients: a 2-year prospective, longitudinal study. Gynecol Oncol. 2014; 133(3):518-25

64. Ficarra V, Novella G, Sarti A, Novara G, Galfano A, Cavalleri S, et al. Psychosocial well-being and general health status after surgical treatment for localized renal cell carcinoma. Int Urol Nephrol. 2002;34(4):441-6.

65. Galbraith ME, Arechiga A, Ramirez J, Pedro LW. Prostate cancer survivors' and partners' self-reports of health-related quality of life, treatment symptoms, and marital satisfaction 2.5-5.5 years after treatment. Oncol Nurs Forum. 2005;32(2):E30-41.

66. Ganz PA, Desmond KA, Leedham B, Rowland JH, Meyerowitz BE, Belin TR. Quality of life in long-term, disease-free survivors of breast cancer: a followup study. J Natl Cancer Inst. 2002;94(1):39-49.

67. Gjorup CA, Groenvold M, Hendel HW, Dahlstroem K, Drzewiecki KT, Klausen TW, et al. Health-related quality of life in melanoma patients: impact of melanoma-related limb lymphoedema. Eur J Cancer. 2017;85:122-32.

68. Goswami S, Mongelli M, Peipert BJ, Helenowski I, Yount SE, Sturgeon C. Benchmarking health-related quality of life in thyroid cancer versus other cancers and United States normative data. Surgery. 2018;164(5):986-92.

69. Goswami S, Peipert BJ, Mongelli MN, Kurumety SK, Helenowski IB, Yount SE, et al. Clinical factors associated with worse quality-of-life scores in United States thyroid cancer survivors. Surgery. 2019;166(1):69-74.

70. Gulbrandsen N, Hjermstad MJ, Wisløff F, Group NMS. Interpretation of quality of life scores in multiple myeloma by comparison with a reference population and assessment of the clinical importance of score differences. Eur J Haematol. 2004;72(3):172-80.
71. Hallas CN, Patel N, Oo A, Jackson M, Murphy P, Drakeley MJ, et al. Five-year survival following oesophageal cancer resection: psychosocial functioning and quality of life. Psychol Health Med. 2001;6(1):85-94.

72. Hammer SM, Brown JC, Segal S, Chu CS, Schmitz KH. Cancer-related impairments influence physical activity in uterine cancer survivors. Med Sci Sports Exerc. 2014;46(12):2195-201.

73. Harju E, Rantanen A, Helminen M, Kaunonen M, Isotalo T, Åstedt-Kurki $P$. Health-related quality of life in patients with prostate cancer and their spouses: results from a longitudinal study. Eur J Oncol Nurs. 2018:37:51-5.

74. Helgeson VS, Tomich PL. Surviving cancer: a comparison of 5-year diseasefree breast cancer survivors with healthy women. Psychooncology. 2005; 14(4):307-17.

75. Hellstadius Y, Lagergren J, Zylstra J, Gossage J, Davies A, Hultman CM, et al. A longitudinal assessment of psychological distress after oesophageal cancer surgery. Acta Oncol. 2017;56(5):746-52.

76. Holterhues C, Cornish D, van de Poll-Franse LV, Krekels G, Koedijk F, Kuijpers D, et al. Impact of melanoma on patients' lives among 562 survivors: a Dutch population-based study. Arch Dermatol. 2011;147(2):177-85.

77. Holzner B, Kemmler G, Kopp M, Nguyen-Van-Tam D, Sperner-Unterweger B, Greil R. Quality of life of patients with chronic lymphocytic leukemia: results of a longitudinal investigation over 1 yr. Eur J Haematol. 2004;72(6):381-9.

78. Høyer M, Johansson B, Nordin K, Bergkvist L, Ahlgren J, Lidin-Lindqvist A, et al. Health-related quality of life among women with breast cancer-a population-based study. Acta Oncol. 2011;50(7):1015-26.

79. Hsu T, Ennis M, Hood N, Graham M, Goodwin PJ. Quality of life in long-term breast cancer survivors. J Clin Oncol. 2013;31(28):3540-8.

80. Hu L-Y, Ku F-C, Wang Y-P, Shen C-C, Hu Y-W, Yeh C-M, et al. Anxiety and depressive disorders among patients with esophageal cancer in Taiwan: a nationwide population-based study. Support Care Cancer. 2015;23(3):733-40.

81. Husson O, Haak HR, Buffart LM, Nieuwlaat W-A, Oranje WA, Mols F, et al. Health-related quality of life and disease specific symptoms in long-term thyroid cancer survivors: a study from the population-based PROFILES registry. Acta Oncol. 2013;52(2):249-58.

82. Jensen RE, Arora NK, Bellizzi KM, Rowland JH, Hamilton AS, Aziz NM, et al. Health-related quality of life among survivors of aggressive non-Hodgkin lymphoma. Cancer. 2013;119(3):672-80.

83. Jordan K, Proskorovsky I, Lewis P, Ishak J, Payne K, Lordan N, et al. Effect of general symptom level, specific adverse events, treatment patterns, and patient characteristics on health-related quality of life in patients with multiple myeloma: results of a European, multicenter cohort study. Support Care Cancer. 2014;22(2):417-26

84. Kerleau C, Guizard A-V, Daubisse-Marliac L, Heutte N, Mercier M, Grosclaude $P$, et al. Long-term quality of life among localised prostate cancer survivors: QALIPRO population-based study. Eur J Cancer. 2016;63:143-53.

85. Kim SB, Williams SB, Cheng S-C, Sanda MG, Wagner AA. Evaluation of patient-reported quality-of-life outcomes after renal surgery. Urology. 2012; 79(6):1268-73

86. Lagergren P, Avery KNL, Hughes R, Barham CP, Alderson D, Falk SJ, et al. Health-related quality of life among patients cured by surgery for esophageal cancer. Cancer. 2007;110(3):686-93.

87. Lee Jl, Kim SH, Tan AH, Kim HK, Jang HW, Hur KY, et al. Decreased healthrelated quality of life in disease-free survivors of differentiated thyroid cancer in Korea. Health Qual Life Outcomes. 2010;8(1):101.

88. Leung J, Pachana NA, McLaughlin D. Social support and health-related quality of life in women with breast cancer: a longitudinal study. Psychooncology. 2014;23(9):1014-20.

89. Li M, Wang L. The associations of psychological stress with depressive and anxiety symptoms among Chinese bladder and renal cancer patients: the mediating role of resilience. PLoS One. 2016;11(4):e0154729. https://doi.org/ 10.1371/journal.pone.0154729.

90. Lin LL, Brown JC, Segal S, Schmitz KH. Quality of life, body mass index, and physical activity among uterine cancer patients. Int J Gynecol Cancer. 2014; 24(6):1027.

91. Mehnert A, Lehmann C, Graefen M, Huland H, Koch U. Depression, anxiety, post-traumatic stress disorder and health-related quality of life and its association with social support in ambulatory prostate cancer patients. Eur J Cancer Care. 2010;19(6):736-45.

92. Michael YL, Kawachi I, Berkman LF, Holmes MD, Colditz GA. The persistent impact of breast carcinoma on functional health status: prospective evidence from the Nurses' Health Study. Cancer. 2000;89(11):2176-86. 
93. Mols F, Aaronson NK, Vingerhoets AJ, Coebergh JWW, Vreugdenhil G, Lybeert ML, et al. Quality of life among long-term non-Hodgkin lymphoma survivors: a population-based study. Cancer. 2007;109(8):1659-67.

94. Mols F, Oerlemans S, Vos AH, Koster A, Verelst S, Sonneveld P, et al. Healthrelated quality of life and disease-specific complaints among multiple myeloma patients up to $10 \mathrm{yr}$ after diagnosis: results from a populationbased study using the PROFILES registry. Eur J Haematol. 2012;89(4):311-9.

95. Mols F, Schoormans D, Smit JWA, Netea-Maier RT, Links TP, van der Graaf WTA, et al. Age-related differences in health-related quality of life among thyroid cancer survivors compared with a normative sample: results from the PROFILES registry. Head Neck. 2018;40(10):2235-45.

96. Mols F, van de Poll-Franse LV, Vingerhoets AJJM, Hendrikx A, Aaronson NK, Houterman S, et al. Long-term quality of life among Dutch prostate cancer survivors. Cancer. 2006;107(9):2186-96.

97. Oberoi D, White $V$, Seymour J, Prince HM, Harrison S, Jefford M, et al. The course of anxiety, depression and unmet needs in survivors of diffuse large B cell lymphoma and multiple myeloma in the early survivorship period. J Cancer Surviv. 2017;11(3):329-38.

98. Ostroff JS, Krebs P, Coups EJ, Burkhalter JE, Feinstein MB, Steingart RM, et al. Health-related quality of life among early-stage, non-small cell, lung cancer survivors. Lung Cancer. 2011;71(1):103-8.

99. Palesh O, Aldridge-Gerry A, Bugos K, Pickham D, Chen JJ, Greco R, et al. Health behaviors and needs of melanoma survivors. Support Care Cancer. 2014;22(11):2973-80

100. Peuckmann V, Ekholm O, Rasmussen NK, Møller S, Groenvold M, Christiansen P, et al. Health-related quality of life in long-term breast cancer survivors: nationwide survey in Denmark. Breast Cancer Res Treat. 2007;104(1):39.

101. Rauma V, Sintonen $H$, Räsänen JV, Salo JA, llonen IK. Long-term lung cancer survivors have permanently decreased quality of life after surgery. Clin Lung Cancer. 2015;16(1):40-5.

102. Reimer J, Esser J, Fleiss A, Hessel A, Anastassiou G, Krausz M, et al. Quality of life in patients with malignant choroidal melanoma after radiotherapy. Graefes Arch Clin Exp Ophthalmol. 2003;241(5):371-7.

103. Sanda MG, Dunn RL, Michalski J, Sandler HM, Northouse L, Hembroff L, et al. Quality of life and satisfaction with outcome among prostate-cancer survivors. N Engl J Med. 2008;358(12):1250-61.

104. Sarna L, Padilla G, Holmes C, Tashkin D, Brecht ML, Evangelista L. Quality of life of long-term survivors of non-small-cell lung cancer. J Clin Oncol. 2002; 20(13):2920-9.

105. Schlesinger-Raab A, Schubert-Fritschle G, Hein R, Stolz W, Volkenandt M, Hölzel D, et al. Quality of life in localised malignant melanoma. Ann Oncol. 2010;21(12):2428-35

106. Smith SK, Crespi CM, Petersen L, Zimmerman S, Ganz PA. The impact of cancer and quality of life for post-treatment non-Hodgkin lymphoma survivors. Psycho-oncology. 2010;19(12):1259-67.

107. Smith SK, Mayer DK, Zimmerman S, Williams CS, Benecha H, Ganz PA, et al. Quality of life among long-term survivors of non-Hodgkin lymphoma: a follow-up study. J Clin Oncol. 2013;31(2):272

108. Smith SK, Zimmerman S, Williams CS, Zebrack BJ. Health status and quality of life among non-Hodgkin lymphoma survivors. Cancer. 2009;115(14):3312-23.

109. Syrjala KL, Langer SL, Abrams JR, Storer B, Sanders JE, Flowers ME, et al. Recovery and long-term function after hematopoietic cell transplantation for leukemia or lymphoma. Jama. 2004;291(19):2335-43.

110. Syrjala KL, Langer SL, Abrams JR, Storer BE, Martin PJ. Late effects of hematopoietic cell transplantation among 10-year adult survivors compared with case-matched controls. J Clin Oncol. 2005;23(27):6596-606.

111. Tan LGL, Nan L, Thumboo J, Sundram F, Tan LKS. Health-related quality of life in thyroid cancer survivors. Laryngoscope. 2007;117(3):507-10.

112. Teoh AYB, Yan Chiu PW, Wong TCL, Liu SYW, Hung Wong SK, Ng EKW. Functional performance and quality of life in patients with squamous esophageal carcinoma receiving surgery or chemoradiation: results from a randomized trial. Ann Surg. 2011;253(1):1-5.

113. Thong MS, Mols F, Lemmens VE, Creemers G-J, Slooter GD, van de PollFranse LV. Impact of chemotherapy on health status and symptom burden of colon cancer survivors: a population-based study. Eur J Cancer. 2011; 47(12):1798-807.

114. Tomich PL, Helgeson VS. Five years later: a cross-sectional comparison of breast cancer survivors with healthy women. Psychooncology. 2002;11(2):154-69.

115. Trentham-Dietz A, Sprague BL, Klein R, Klein BE, Cruickshanks KJ, Fryback DG, et al. Health-related quality of life before and after a breast cancer diagnosis. Breast Cancer Res Treat. 2008;109(2):379-87.
116. Van der Poel M, Oerlemans S, Schouten H, van de Poll-Franse L. Elderly multiple myeloma patients experience less deterioration in health-related quality of life than younger patients compared to a normative population: a study from the population-based PROFILES registry. Ann Hematol. 2015; 94(4):651-61.

117. Verhaar S, Vissers PA, Maas H, van de Poll-Franse LV, van Erning FN, Mols F. Treatment-related differences in health related quality of life and disease specific symptoms among colon cancer survivors: results from the population-based PROFILES registry. Eur J Cancer. 2015;51(10):1263-73.

118. Waldmann A, Nolte S, Pritzkuleit R, Breitbart EW, Katalinic A. Different aspects of self-reported quality of life in 450 German melanoma survivors. Cancers. 2011;3(2):2316-32.

119. Yang $P$, Cheville AL, Wampfler JA, Garces YI, Jatoi A, Clark MM, et al. Quality of life and symptom burden among long-term lung cancer survivors. J Thorac Oncol. 2012;7(1):64-70.

120. Zhang Y, Joshy G, Glass K, Banks E. Physical functional limitations and psychological distress in people with and without colorectal cancer: findings from a large Australian study. J Cancer Survivorship. 2020;14(6):894-905.

121. Deimling GT, Kahana B, Bowman KF, Schaefer ML. Cancer survivorship and psychological distress in later life. Psychooncology. 2002;11(6):479-94.

122. Osoba D. Health-related quality of life and cancer clinical trials. Ther Adv Med Oncol. 2011;3(2):57-71.

123. Butow $P$, Girgis $A$, Goldstein $D$, Eisenbruch $M$, Schofield $P$, Jefford $M$, et al. Unmet needs in Chinese, Greek and Arabic speaking cancer patients in Australia. Psychooncology. 2009;17(9):S7.

124. Rothman KJ, Gallacher JE, Hatch EE. Why representativeness should be avoided. Int J Epidemiol. 2013;42(4):1012-4.

125. Mealing NM, Banks E, Jorm LR, Steel DG, Clements MS, Rogers KD. Investigation of relative risk estimates from studies of the same population with contrasting response rates and designs. BMC Med Res Methodol. 2010;10:26.

126. Nekhlyudov L, Mollica MA, Jacobsen PB, Mayer DK, Shulman LN, Geiger AM. Developing a quality of cancer survivorship care framework: implications for clinical care, research, and policy. J Natl Cancer Inst. 2019;111(11):1120-30.

127. Butow P, Price MA, Shaw JM, Turner J, Clayton JM, Grimison P, et al. Clinical pathway for the screening, assessment and management of anxiety and depression in adult cancer patients: Australian guidelines. Psychooncology. 2015;24(9):987-1001.

128. Jefford M, Koczwara B, Emery J, Thornton-Benko E, Vardy J. The important role of general practice in the care of cancer survivors. Australian Journal for General Practitioners. 2020;49:288-92.

129. Edmondson AJ, Birtwistle JC, Catto JWF, Twiddy M. The patients' experience of a bladder cancer diagnosis: a systematic review of the qualitative evidence. J Cancer Surviv. 2017;11(4):453-61.

130. Antoni MH. Psychosocial intervention effects on adaptation, disease course and biobehavioral processes in cancer. Brain Behav Immun. 2013;30(Suppl): 88-98.

131. Mollica MA, Mayer DK, Oeffinger KC, Kim Y, Buckenmaier SS, Sivaram S, et al. Follow-up care for breast and colorectal cancer across the globe: survey findings from 27 countries. JCO Glob Oncol. 2020;6:1394-411.

\section{Publisher's Note}

Springer Nature remains neutral with regard to jurisdictional claims in published maps and institutional affiliations.

Ready to submit your research? Choose BMC and benefit from:

- fast, convenient online submission

- thorough peer review by experienced researchers in your field

- rapid publication on acceptance

- support for research data, including large and complex data types

- gold Open Access which fosters wider collaboration and increased citations

- maximum visibility for your research: over $100 \mathrm{M}$ website views per year

At $\mathrm{BMC}$, research is always in progress.

Learn more biomedcentral.com/submissions 